\title{
GENETIC DIVERSITY BETWEEN AND WITHIN POPULATIONS OF Handroanthus heptaphyllus (VELL.) MATTOS USING MICROSATELLITE MARKERS ${ }^{1}$
}

\author{
Neide Tomita Mori², Mario Luiz Teixeira de Moraes³, Caroline Midori Morita ${ }^{4}$, Edson Seizo Mori ${ }^{5}$
}

(received: April 15, 2010; accepted: September 29, 2011)

\begin{abstract}
Handroanthus heptaphyllus (Vell.) Mattos, popularly known as ipê-roxo, is a species of the family Bignoneaceae much appreciated for its beauty, excellent quality wood which is used for making medicinal products and also in reforestation programs of degraded areas, as well as landscaping and restoration. The aim of this study was to investigate the genetic diversity between and within populations of $H$. heptaphyllus using microsatellite markers. The 192 seedlings were produced from seeds collected on 30 trees into the two populations of natural forest fragments in Botucatu region, São Paulo, Brazil. Eight microsatellite loci were analyzed, with allelic polymorphism varying from six alleles for locus TAU22 to 14 alleles for loci TAU12, TAU30, and TAU31, with an expected mean number of alleles per locus $\left(\hat{A}_{e}\right)$ of 4.9. The mean expected heterozygosity $\left(\hat{H}_{e}\right)$ for the two populations was 0.785 , the mean observed heterozygosity $\left(\hat{H}_{o}\right)$ was 0.609 , and the fixation index $(\hat{F})$ was low between populations, with a mean of 0.222 . The gene differentiation between the two populations $\left(\hat{G}_{S T}\right.$ ') was 0.100 . We concluded that the higher genetic diversity is within populations; therefore, as far as germplasm collection programs in Botucatu region are concerned, it is recommended that a larger sampling of individuals should be considered within populations, thereby providing good genetic representativeness. The populations have enough genetic diversity to support genetic improvement and germplasm preservation programs.
\end{abstract}

Key words: Germplasm, molecular markers, genetic diversity.

\section{DIVERSIDADE GENÉTICA ENTRE E DENTRO DE POPULAÇÕES DE Handroanthus heptaphyllus (VELL.) MATTOS POR MARCADORES MICROSSATÉLITES}

RESUMO: Handroanthus heptaphyllus (Vell.) Mattos, popularmente conhecida por ipê-roxo, é uma espécie pertencente à família Bignoneaceae, muito apreciada por sua beleza, madeira de excelente qualidade e utilizada em produtos medicinais e programas de reflorestamento de áreas degradadas, paisagismo e restauração. Neste trabalho, objetivou-se estudar a diversidade genética entre e dentro das populações de H. heptaphyllus por meio de marcadores microssatélites. Foram estudadas 192 plântulas, formadas a partir de sementes colhidas de duas populações, em um total de 30 árvores, de fragmentos florestais naturais na região de Botucatu - SP. Foram analisados oito locos microssatélites, com polimorfismo alélico, variando de seis alelos para o loco TAU22 a 14 alelos para os locos TAU12, TAU30 e TAU31, com número efetivo médio de alelos por loco (Â.) igual a 4,9. As médias para a heterozigosidade esperada $\left(\hat{H}_{e}\right)$, para as duas populações foi de 0,785, a heterozigosidade observada $\left(\hat{H}_{o}\right)$ foi de 0,609 e o índice de fixação $(\hat{F})$ variou pouco entre as populações, com média de 0,222. O valor médio da divergência genética entre as duas populações $\left(\hat{G}_{S T}\right.$ ') foi de 0,100. Conclui-se que a maior diversidade genética ocorre dentro das populações; portanto, em programa de coleta de germoplasma, para a região de Botucatu, é recomendado realizar uma maior amostragem de indivíduos dentro das populações, o que possibilitaria uma boa representatividade genética. As populações estudadas possuem diversidade genética para subsidiar programas de melhoramento genético e conservação de germoplasma.

Palavras-chave: Germoplasma, marcadores moleculares, diversidade genética.

\section{INTRODUCTION}

The fragmentation of forests by explorers and the urbanization advent have both had a tremendous impact on biodiversity, upsetting the balance of ecosystems, isolating habitats and changing the behavioral pattern of both fauna and flora by disrupting gene flow between fragments (KAGEYAMA et al., 2003). As the result, the genetic diversity of forest tree species has been decreasing.

Typically, Handroanthus heptaphyllus (Velloso) Mattos occurs in areas of rain forests. Commonly known as ipê-roxo, the species has become increasingly popular

\footnotetext{
${ }^{1}$ Excerpt from the first author's M.Sc. Dissertation of the Graduate Program in Forest Science, UNESP, Campus of Botucatu - SP, Brazil.

${ }^{2}$ Zootechnician, M.Sc. in Forest Science - Universidade Estadual Paulista Julio de Mesquita Filho/UNESP - Campus de Botucatu - Faculdade de Ciências Agronômicas - Av. José Barbosa de Barros, 1780 - 18.610-370 - Botucatu, SP, Brasil - nkimie@hotmail.com

${ }^{3}$ Agronomic Engineer, Professor Ph.D. in Plant Breeding - Universidade Estadual Paulista Julio de Mesquita Filho/UNESP - Campus de Ilha Solteira Faculdade de Engenharia - Rua Monção, 226 - 15.385-000 - Ilha Solteira, SP, Brasil - teixeira@agr.feis.unesp.br

${ }^{4}$ Biologist - Universidade Estadual Paulista Julio de Mesquita Filho/UNESP - Campus de Botucatu - Faculdade de Ciências Agronômicas Av. José Barbosa de Barros, 1780 - 18.610-370 - Botucatu, SP, Brasil

${ }^{5}$ Forest Engineer, Professor Ph.D. in Plant Breeding - Universidade Estadual Paulista Julio de Mesquita Filho/UNESP - Campus de Botucatu Faculdade de Ciências Agronômicas - Av. José Barbosa de Barros, 1780 - 18.610-370 - Botucatu, SP, Brasil - esmori@fca.unesp.br
}

Cerne, Lavras, v. 18, n. 1, p. 9-15, jan./mar. 2012 
for several environmental and economic issues. The bark is widely used for making medicinal syrups and the wood is hugely popular for its high economic value. It has also been used in recovery and restoration programs on degraded areas, given the decreasing occurrence of this species in natural habitats (ETTORI et al., 1996), being also used as an ornamental plant in urban public squares and for restoring riparian vegetation, since the species develops well on soils adjacent to watercourses (MOREIRA; SOUZA, 1987).

According to Jankowsky et al. (1990), the species of genus Handroanthus provide hard and heavy wood with low retractibility and density about $1,070 \mathrm{~kg} \cdot \mathrm{m}^{-3}$; the wood is dark and has pale sapwood (PAULA; ALVES, 1997). Those characteristics have stirred the interest of timber companies and as a consequence the exploration has led to a large decrease in its natural occurrence. However, the species does not reproduce easily in natural environments and seed viability is very low under natural conditions (VIEIRA et al., 2010).

Despite the predatory exploration, the use of the species on a commercial scale is very limited and its seeds are still being collected from natural populations. So far, no genetic improvement programs have been created to offer improved seeds, whether for commercial purposes or even for creation of seed orchards.

In order to use a particular species for reforestation, conservation, or improvement programs, it is important to study its mating system and the genetic structure of populations through molecular markers, to know how genetic diversity is distributed within and between populations. It can help to acquire the necessary knowledge to ensure suitable population management, helping to stablish strategies to support genetic improvement and germplasm preservation programs (BROWN, 1978).

The seasonal semi deciduous forest is one of the forest subtypes that compose the Atlantic forest biome. Today, the total area of remnants of that type of forest in São Paulo State corresponds to less than 5\% of the total area by the late nineteenth century (RAMOS et al., 2007) and $H$. heptaphyllus is a representative species of that vegetation. Therefore, the objective of the study was to investigate the genetic diversity between and within populations of $H$. heptaphyllus using microsatellite markers, looking to support genetic resource development and germplasm preservation programs for the species in region strongly affected by the impacts of forest fragmentation.

Cerne, Lavras, v. 18, n. 1, p. 9-15, jan./mar. 2012

\section{MATERIAL AND METHODS}

\subsection{Study site}

The research was conducted in the municipality of Botucatu-SP, Brazil, in the region of Médio Tietê Basin. Due to heavy urbanization, the studied region presents many small forest fragments (Figure 1).

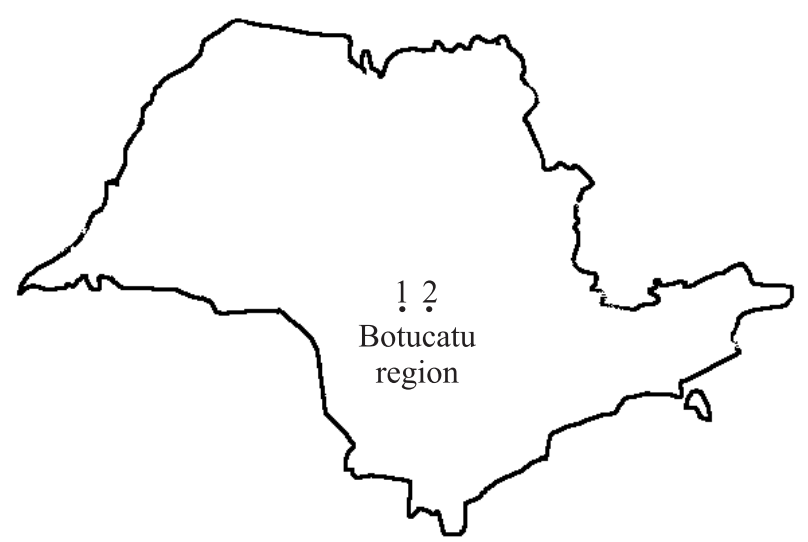

Figure 1 - Local of two studied Handroanthus heptaphyllus populations, in Botucatu region, São Paulo State, Brazil.

Figura 1 - Localização das duas populações estudadas de Handroanthus heptaphyllus na região de Botucatu - SP.

Two populations were demarcated in those forest fragments: population 1 (Lageado) consisted of 115 seedlings originated from 15 mother trees while population 2 (Indiana) was composed of 77 seedlings originated from 15 mother trees. The idea was to depict the representiveness occurrence of the species in the region, considering locally its low population density.

\subsection{Microsatellite analysis}

For each individual, three leaflets were collected from adult leaves and then stored at room temperature in a dry environment. For DNA extraction, $150 \mathrm{mg}$ of plant material were used per sample. The protocol proposed by Ferreira and Grattapaglia (1995) was used. The primers were transferred from Handroanthus aureus, as developed by Braga et al. (2007), considering their respective annealing temperatures, through PCR procedures, for replication of DNA fragments (Table $1)$. The DNA fragments were separated by $6 \%$ bis/ acrylamide gels. The gel was developed using nitrate of silver, according to the procedure described by Creste et al. (2001). 
Table 1 - Primers developed by Braga et al. (2007) and transferred to Handroanthus heptaphyllus, with their respective annealing temperatures.

Tabela 1 - Primers, desenvolvidos por Braga et al. (2007), que foram transferidos para Handroanthus heptaphyllus, com suas respectivas temperaturas de anelamento.

\begin{tabular}{clc}
\hline Primer & \multicolumn{1}{c}{ Primer sequence } & Annealing temperature $\left({ }^{\circ} \mathrm{C}\right)$ \\
\hline \multirow{2}{*}{ Tau 12} & F: CATCATCAACGTCAAGATCA & 56 \\
& R: CATTCTAGTCTTCCATAATAAGT & 56 \\
Tau 14 & F: GGTAACGGATTGCTGGTTGT & 56 \\
\hline \multirow{2}{*}{ Tau 15} & R: CATTGCGAATGGCCTATGGT & 56 \\
\hline \multirow{2}{*}{ Tau 21} & F: TTTGAGGGGTTGAAGCATTT & 56 \\
\hline \multirow{2}{*}{ Tau 22} & F: CTTTTGGGGGTCTTTGGAAT & 56 \\
\hline \multirow{2}{*}{ Tau 27} & R: TGAAAGAGACAGAGACAAAGATACA & 56 \\
\hline \multirow{2}{*}{ Tau 30} & F: TATCTCTCCGCCGTACACCT & 56 \\
\hline Tau 31 & R: CCAATCGAAGAGCCCATTTA & 56 \\
\hline
\end{tabular}

\subsection{Data analysis}

Based on zymograms, the following parameters were estimated: allele frequencies $\left(\hat{p}_{i}\right)$, mean number of alleles per locus $(\hat{A})$, derived from the arithmetic average of loci; expected number of alleles per locus $\left(\hat{A}_{e}=\frac{1}{1-\hat{H}_{e}}\right)$ Nei (1978); observed heterozygosity $\left(\hat{H}_{o}=1-\sum P_{i i}\right)$; expected heterozygosity $\left(\hat{H}_{e}=1-\sum p_{i}^{2}\right)$ and fixation index $\left(\hat{F}=1-\frac{\hat{H}_{o}}{\hat{H}_{e}}\right)$, according to Weir (1996). The genetic structure between populations was derived from statistics proposed by Nei (1978), where: $\hat{H}_{T}$ is total gene diversity; $\hat{G}_{S T}$ is coefficient of gene diferentiation between populations and $\hat{H}_{S}$ is gene diversity within populations, using FSTAT software (GOUDET, 2002). The estimation of $\hat{G}_{S T}$, however, was standardized $\hat{G}_{S T}$, according to Hedrick (2005), and presented as follow: $\hat{G}_{S T}^{\prime}=\frac{\hat{G}_{S T}\left(1+\hat{H}_{S}\right)}{\left(1-\hat{H}_{S}\right)}$.

\section{RESULTS AND DISCUSSION}

\subsection{Genetic diversity and fixation index}

Eight loci in two populations of $H$. heptaphyllus were found to be all polymorphic. A total of 63 alleles were found and the expected number of alleles per locus $\left(\hat{A_{e}}\right)$ ranged from 3.4 (TAU 21) to 6.7 (TAU 14) in the population 1, and from 3.1 (TAU 30) to 8.0 (TAU 31) in the population 2, with mean value of 4.9 between populations (Table 2). Estimates of this parameter in other recent studies were found to range from 2.9 (MENDES, 2009) for Cedrela fissilis to 10.11 alleles (SILVA, 2010) for Tabebuia aurea.

The observed heterozygosity $\left(\hat{H}_{o}\right)$ ranged from 0.461 (TAU 22, population 2) to 0.729 (TAU 31, population 2), while the expected heterozygosity $\left(\hat{H}_{e}\right)$ ranged from a minimum of 0.673 (TAU 30, population 2) to a maximum of 0.875 (TAU 31, population 2), corresponding to a mean of $0.609\left(\hat{H}_{o}\right)$ and $0.785\left(\hat{H}_{e}\right)$ (Table 2). These mean estimates are higher than the results found by Mendes (2009) for Cedrela fissilis (0.566 and 0.646) and by Viégas (2009) for Myracrodruon urundeuva

Cerne, Lavras, v. 18, n. 1, p. 9-15, jan./mar. 2012 
Table 2 - Expected mean number of alleles per locus $\left(\hat{A_{e}}\right)$, observed heterozygosity $\left(\hat{H}_{o}\right)$, expected heterozygosity $\left(\hat{H}_{e}\right)$ and fixation index $(\hat{F})$ for eight loci, in two populations of Handroanthus heptaphyllus.

Tabela 2-Número médio de alelos por loco $(\hat{A})$, heterozigosidade observada $\left(\hat{H}_{o}\right)$, heterozigosidade esperada $\left(\hat{H}_{e}\right)$ e índice de fixação $(\hat{F})$ para os oito locos e duas populações de Handroanthus heptaphyllus.

\begin{tabular}{cccccc}
\hline Population & Locus & $\hat{A_{e}}$ & $\hat{H}_{o}$ & $\hat{H}_{e}$ & $\hat{F}$ \\
\hline & TAU 12 & 6.1 & 0.699 & 0.836 & 0.164 \\
& TAU 14 & 6.7 & 0.666 & 0.851 & 0.217 \\
& TAU 15 & 4.2 & 0.583 & 0.762 & 0.235 \\
& TAU 21 & 3.4 & 0.567 & 0.702 & 0.192 \\
& TAU 22 & 4.4 & 0.558 & 0.771 & 0.276 \\
& TAU 27 & 4.9 & 0.667 & 0.797 & 0.163 \\
& TAU 30 & 3.5 & 0.509 & 0.714 & 0.287 \\
& TAU 31 & 5.7 & 0.632 & 0.823 & 0.232 \\
& Mean & 4.7 & 0.610 & 0.782 & 0.221 \\
\hline \multirow{5}{*}{2} & TAU 12 & 5.8 & 0.610 & 0.826 & 0.262 \\
& TAU 14 & 5.3 & 0.667 & 0.811 & 0.178 \\
& TAU 15 & 6.2 & 0.545 & 0.838 & 0.350 \\
& TAU 21 & 3.3 & 0.616 & 0.694 & 0.112 \\
& TAU 22 & 4.7 & 0.461 & 0.787 & 0.414 \\
& TAU 27 & 5.0 & 0.603 & 0.798 & 0.244 \\
& TAU 30 & 3.1 & 0.634 & 0.673 & 0.058 \\
& TAU 31 & 8.0 & 0.729 & 0.875 & 0.167 \\
& Mean & 5.1 & 0.608 & 0.788 & 0.223 \\
\hline \multirow{2}{*}{ Total mean } & & 4.9 & 0.609 & 0.785 & 0.222 \\
\hline
\end{tabular}

(0.601 and 0.713), yet lower than results found by Silva (2010) for Tabebuia aurea ( 0.627 and 0,881$)$, by Carvalho (2009) for Copaifera langsdorffii $(0,757$ and 0,893$)$, and by Tarazi (2009) also for Copaifera langsdorffii $(0,814$ and 0,876), respectively for $\hat{H}_{o}$ and $\hat{H}_{e}$. In a study describing primers for Tabebuia aurea, Braga et al. (2007) obtained 0.913 for expected heterozygosity, which is above the mean value found in this work (0.785), and 0.578 for observed heterozygosity, which is below the mean value found at the present study (0.609).

The fixation index $(\hat{F})$ followed the same trend with a wider range of variation in population 2 , with a minimum of 0.058 (TAU 30) and a maximum of 0.414 (TAU 22), and a mean of 0.222 when both populations were considered, suggesting deviations on the Hardy-Weinberg equilibrium due to homozygous excess, probably due to inbreeding.
If compared with data of some tropical species literature, the mean estimate of $\hat{F}(0.222)$ is higher than the results found by Tarazi (2009) for Copaifera langsdorffii (0.071), by Carvalho (2009) also for Copaifera langsdorffii (0.152), and by Viegás (2009) for Myracrouon urundeuva (0.210), yet it is lower than results found by Mendes (2009) for Cedrela fissilis (0.250), by Silva (2010) for Tabebuia aurea (0.294), and by Braga et al. (2007) also for Tabebuia aurea (0.367).

Based on the estimated parameters $\left(\hat{A}_{e}, \hat{H}_{o}\right.$ and $\hat{H}_{e}$ ) to help identify genetic diversity, and the fixation index $(\hat{F})$, it can be inferred that population 2 had slight superiority in the mean values of loci and a wider range of variation for those parameters. However, considering the size of those populations and the conditions of fragmentation there are an increase of inbreeding levels than expected over time as a function of likely relatedness of generations, potentially decreasing heterozygous and showing higher structuring within populations. Therefore, effective measures should be taken in order to prevent these populations from remaining isolated and to consequently avoid genetic diversity to decrease for generations. This issue was discussed extensively in studies by Bittencourt and Sebbenn (2007), Gaino et al. (2010), and Sebbenn et al. (2011), on Araucaria angustifolia, Myracroduon urundeuva and Copaifera langsdorffii respectively.

\subsection{Genetic structure between and within populations}

Results of total gene diversity $\left(\hat{H}_{T}=0.794\right.$ or $100 \%)$ show higher diversity within populations $\left(\hat{H}_{s}=\right.$ 0.785 or $98.8 \%)$ and lower gene diversity $\left(\hat{D}_{S T}=0.09\right.$ or $1.2 \%$ ) between populations. Considering only $\hat{G_{S T}}$, low variation was found between loci, the minimum gene diversity of $0.3 \%$ (TAU 27) and the maximum of $2.8 \%$ (TAU 14) were found. However, when the $\hat{G}_{\text {ST }}^{\hat{~}}$ proposed by Hedrick (2005) was used, the variation goes from 2.7\% (TAU 27) to $30.3 \%$ (TAU 14), which is a considerable estimated value. Being more consistent and accurate parameter, $G_{S T}$ was the choice for discussion, indicating a mean variation of $10 \%$ between populations, which is something to be considered inasmuch as the presence or absence of alleles is concerned in either population (Table 3). This variation between the populations was becoming evident when studying the genetic diversity and fixation index parameters, in which a higher range of variation was found in population 2. It is interesting the use of $G_{S T}$ statistic for that dispersion measure. 
Table 3 - Gene diversities: total $\left(\hat{H}_{T}\right)$, within $\left(\hat{H}_{s}\right)$ and between populations $\left(\hat{D_{S T}}\right)$, and the statistics $\hat{G}_{S T}$ of Hedrick (2005) and Nei (1978) between populations of Handroanthus heptaphyllus, for eight microsatellite loci, in Botucatu region, SP, Brazil.

Tabela 3 - Diversidades gênicas: total $\left(\hat{H}_{T}\right)$, dentro $\left(\hat{H}_{s}\right)$ e entre populações $\left(\hat{D_{S T}}\right)$, como também as estatísticas $\hat{G_{S T}}$ de Hedrick (2005) e Nei (1978) entre as populações de Handroanthus heptaphyllus, para os oito locos microssatélites, na região de Botucatu, SP.

\begin{tabular}{lccccc}
\hline \multirow{2}{*}{ Locus } & \multirow{2}{*}{$\hat{H}_{s}$} & \multirow{2}{*}{$\hat{H}_{T}$} & $\hat{D_{S T}}$ & \multicolumn{2}{c}{$\hat{G_{S T}}$} \\
\cline { 5 - 7 } & & & & Nei & Hedrick \\
\hline TAU 12 & 0.831 & 0.838 & 0.007 & 0.008 & 0.087 \\
TAU 14 & 0.831 & 0.855 & 0.024 & 0.028 & 0.303 \\
TAU 15 & 0.800 & 0.811 & 0.011 & 0.013 & 0.117 \\
TAU 21 & 0.698 & 0.701 & 0.003 & 0.004 & 0.022 \\
TAU 22 & 0.779 & 0.789 & 0.010 & 0.012 & 0.097 \\
TAU 27 & 0.797 & 0.800 & 0.003 & 0.003 & 0.027 \\
TAU 30 & 0.694 & 0.703 & 0.009 & 0.013 & 0.072 \\
TAU 31 & 0.849 & 0.858 & 0.009 & 0.011 & 0.135 \\
All & 0.785 & 0.794 & 0.009 & 0.012 & 0.100 \\
\hline
\end{tabular}

Another factor that supports $\hat{G_{S T}}$ statistic is the study of Hamrick (1983) with wind-dispersed seeds of 38 tree species. Although the author worked with isoenzymes, the estimated gene differentiation between populations $\left(\hat{G}_{S T}\right)$ was 0.056 or $5.6 \%$, which is higher than the present result for $H$. heptaphyllus populations (1.2\%). However, when estimating $G_{S T}^{\prime}$ statistic, according to Hamrick (1983), the value was 0.093 or $9.3 \%$, close to the estimate for $H$. heptaphyllus ( 0.100 or $10 \%$ ) at the present study.

Populations of Tabebuia aurea were studied by Silva (2010) in Assis-SP, Pedregulho-SP, Selvíria-MS and Três Lagoas-MS, Brazil, who found a $\hat{G_{S T}}$ mean of 0.025 or $2.5 \%$ and a mean $G_{S T}^{\prime}$ of 0.444 or $44.4 \%$. Estimates above $10 \%$ for $G_{S T}^{\prime}$ were also found by Viegás (2009) between two populations of Myracrodruon urundeuva (Aramina-SP and Selvíria-MS, Brazil): 15.9\% (pollen) and $23.5 \%$ (ovule). This high gene differentiation between populations was expected because of the geographic distance between them, obstructing the gene flow. Isolation and differing historical events in each population, therefore, result in higher gene differentiation, as opposed to geographic proximity which facilitates gene exchange (VIÉGAS, 2009), as is the statement of two populations of $H$. heptaphyllus in Botucatu region.

\subsection{Seed collection for genetic resource development}

One of the objectives of this study was to create conditions to support germplasm preservation programs for $H$. heptaphyllus, in Botucatu region, São Paulo, Brazil, area that is strongly affected by the impacts of forest fragmentation. According to Sebbenn (2002, 2003, 2006), an estimated number of trees for seed collection intended for forest tree improvement would be 29 to 76 , with an average of 45 . Therefore, even if collecting from both populations, only 30 trees are found in the study region, which is below the average considered optimal and just one tree above the minimum considered reasonable. It gives an idea on deforestation level of the studied region, which makes seed collection virtually impossible for establishment of seed orchards, since that would require 44 to 114 unrelated trees, with an average of 67 parent trees. To stablish seed orchard it is necessary a gene enrichment from the other preferably neighbor regions.

\section{CONCLUSIONS}

The populations of $H$. heptaphyllus have shown allelic polymorphism in all eight microsatellite loci.

The species genetic diversity is compatible with results from other tropical tree species. The existing genetic diversity is nonetheless sufficient to support genetic improvement and germplasm conservation programs for the species. However, there are signs of inbreeding as a result of forest fragmentation in Botucatu region, Brazil.

High genetic variation was found within populations, suggesting that a larger sampling of individuals is required, however the divergence between populations cannot be ignored.

\section{REFERENCES}

BITTENCOURT, J. M.; SEBBENN, A. M. Patterns of pollen and seed dispersal in a small fragmented population of a wind pollinated Araucaria angustifolia in southern Brazil. Journal of Heredity, Washington, v. 99, p. 589-591, 2007.

BRAGA, A. C.; REIS, A. M. M.; LEOI, L. T.; PEREIRA, R. W.; COLLEVATTI, R. G. Development and characterization of microsatellite markers for the tropical tree species Tabebuia aurea (Bignoniaceae). Molecular Ecology Notes, Oxford, v. 7, n. 1, p. 53-56, 2007.

BROWN, A. H. D. Isozymes, plant popularion genetics structure and genetic conservation. Theoretical and Applied Genetics, Berlin, v. 52, n. 4, p. 145-157, 1978.

Cerne, Lavras, v. 18, n. 1, p. 9-15, jan./mar. 2012 
CARVALHO, A. C. M. Fluxo de pólen e sementes em população isolada de Copaifera langsdorffii Desf.

(Leguminosae - Caesalpinioideae) em um fragmento florestal localizado em área urbana. 2009. 72 p. Dissertação (Mestrado) - Universidade Estadual Paulista, Ilha Solteira, 2009.

CRESTE, S.; TULMANN NETO, A.; FIGUEIRA, A. Detection of single sequence repeat polymorphism in denaturing polyacrylamide sequencing gels by silver staining. Plant Molecular Biology Reporter, Athens, v. 19, n. 4, p. 299-306, 2001.

ETTORI, L. C.; SIQUEIRA, A. C. M.; CAMPOS, O. R. Variabilidade genética em populações de Ipê-roxo - Tabebuia heptaphylla (Vell.) Tol. - para conservação ex situ. Revista do Instituto Florestal, São Paulo, v. 8, n. 1, p. 61-70, 1996.

FERREIRA, M. E.; GRATTAPAGLIA, D. Introdução ao uso de marcadores moleculares em análise genética. 3. ed. Brasília: Embrapa, 1998. 220 p.

GAINO, A. P. S. C.; SILVA, A. M.; MORAES, M. A.; ALVES, P. F.; MORAES, M. L. T.; FREITAS, M. L. M.; SEBBENN, A. M. Understanding the effects of isolation on seed and pollen flow, spatial genetic structure and effective population size of dioecious tropical tree species Myracrodruon urundeuva. Conservation Genetics, Berlin, v. 11, n. 5, p. 1631-1643, 2010.

GOUDET, J. FSTAT version 2.9.3.2: a computer program to calculate F-statistics. Journal of Heredity, Cary, v. 86, p. 485-486, 2002.

HAMRICK, J. L. The distribution of genetic variation within and among natural populations. In: . Genetics and conservation. Menlo Park: Benjamin-Cummings, 1983. p. 335-348.

HEDRICK, P. W. A standardized genetic differentiation measure. Evolution, Lancaster, v. 59, n. 8, p. 1633-1638, 2005.

JANKOWSKY, I. P.; CHIMELO, J. P.; CAVALCANTE, A. A.; GALINA, I. C. M.; NAGAMURA, J. C. S. Madeiras brasileiras. Caxias do Sul: Spectrum, 1990. v. 1, 172 p.

KAGEYAMA, P. Y.; OLIVIERA, R. E.; MORAES, L. F. D.; ENGEL, V. L.; GANDARA, F. B. Restauração ecológica de ecossistemas naturais. Botucatu: Fundação de Estudos e Pesquisas Agrícolas e Florestais, 2003. 340 p.

Cerne, Lavras, v. 18, n. 1, p. 9-15, jan./mar. 2012
MENDES, F. B. G. Diversidade genética de populações de cedro (Cedrela fissilis Vell. (Meliaceae)) no Centro-Sul do Brasil. 2009. 87 p. Tese (Doutorado) - Escola Superior de Agricultura “Luiz de Queiroz”, Piracicaba, 2009.

MOREIRA, T.; SOUZA, E. D. Mata ciliar: vamos abrir os olhos? Revista Globo Rural, São Paulo, v. 2, n. 20, p. 96-102, 1987.

NEI, M. Estimation of average heterozygosity and genetic distance from a small number of individual. Genetics, London, v. 89, p. 583-590, 1978.

PAULA, J. E.; ALVES, J. L. H. Madeiras nativas: anatomia, dendrologia, dendrometria, produção, uso. Brasília: Fundação Mokiti Okada, 1997. 541 p.

RAMOS, V. S.; DURIGAN, G.; FRANCO, G. A. D. C.; SIQUEIRA, M. F. Árvores da floresta estacional semidecidual: guia de identificação de espécies. São Paulo: EDUSP; Biota/FAPESP, 2008. 320 p.

SEBBENN, A. M. Número de árvores matrizes e conceitos genéticos na coleta de sementes para reflorestamentos com espécies nativas. Revista do Instituto Florestal, São Paulo, v. 14, p. 115-132, 2002.

SEBBENN, A. M. Sistema de reprodução em espécies arbóreas tropicais e suas implicações para a seleção de árvores matrizes para reflorestamentos ambientais. In: HIGA, A. R.; SILVA, L. D. (Ed.). Pomar de sementes de espécies florestais nativas. Curitiba: FUPEF, 2006. p. 93-138.

SEBBENN, A. M. Tamanho amostral para conservação ex situ de espécies arbóreas com sistema misto de reprodução. Revista do Instituto Florestal, São Paulo, v. 15, p. 109-124, 2003.

SEBBENN, A. M.; CARVALHO, A. C. M.; FREITAS, M. L. M.; MORAES, S. M. B.; GAINO, A. P. S. C.; SILVA, J. M.; JOLIVET, C.; MORAES, M. L. T. Low levels of realized seed and pollen gene flow and strong spatial genetic structure in a small, isolated and fragmented population of the tropical tree Copaifera langsdorffii Desf. Journal of Heredity, Washington, v. 106, p. 134-145, 2011.

SILVA, M. C. Diversidade genética, sistema de reprodução, estrutura genética espacial e fluxo gênico em Tabebuia aurea (Silva Manso) Benth. \& Hook. f. ex S. Moore no cerrado. 2010. 162 p. Tese (Doutorado) - Escola Superior de Agricultura “Luiz de Queiroz”, Piracicaba, 2010. 
TARAZI, R. Diversidade genética, estrutura genética espacial, sistema de reprodução e fluxo gênico em uma população de Copaifera langsdorffii Desf. no cerrado. 2009. 139 p. Tese (Doutorado) - Escola Superior de Agricultura “Luiz de Queiroz”, Piracicaba, 2009.
VIEIRA, C. V.; SILVA, A. A. da; ALVARENGA, A. A. de; CASTRO, E. M. de; TOOROP, P. E. Stress-associated factors increase after desiccation of germinated seeds of Tabebuia impetiginosa Mart. Plant Growth Regulation, Dordrecht, v. 62, p. 257-263, 2010.

Cerne, Lavras, v. 18, n. 1, p. 9-15, jan./mar. 2012 
